\title{
Consumer value dimensions of rural tourism in Hungary
}

\author{
NoÉMI KULCSÁR ${ }^{1}$
}

\begin{abstract}
Considering the geographical and historical characteristics of Hungary, rural tourism could be one of the key tourism products since the country misses extraordinary natural attractions, seaside or high mountains. Hungary has always been an agricultural country and it is rich in cultural landscape with traditional small villages and rural hospitality. As in Hungary theoretical research on consumer value factors in rural tourism is completely missing the primary aim of our investigation was to conduct a niche survey in rural tourism, which can contribute to the better understanding of the demand side of the market and crystallise the factors with value to tourists. The aim of the pilot study based on qualitative research is to identify and measure consumer value dimensions. In our qualitative research first we completed indicators identified by secondary sources with further indicators, as the result of a small sample consumer survey, then we have refined the created list of indicators on the basis of expert opinions. As the next step of the research we have conducted a quantitative questionnaire-based survey, by which the aim was to identify, interpret and analyse the motivations of rural tourist and the indicator-based consumer value with its major dimensions. In this paper we discuss only the latter phase of our research in more detail. The basis of success of rural tourism in Hungary can be the identification of tourists' motivations, attitudes, as well as factors that carry value for them, since it may reveal useful information both scientifically and practically.
\end{abstract}

Keywords: consumer value, value dimensions, motivation, rural tourism, Hungary

\section{Introduction}

At the beginning of the third millennium we can see that the desire for experiences and intellectual challenges is strengthening and becoming more and more intertwined with the shifting of consumer behaviour from material values towards ethical and intellectual values. This is a clear reaction to the materialistic orientation of the consumer society. Instead of strongly materialistic factors, in the "new economy" intellectual skills and abilities are the major creators of value, in the economic sense. However, a high level of material consumption is also necessary so that post-materialistic values could come forward. Complete industries were built upon these values, such as the production of organic food or sports equipment, as well as rural tourism offering experiences (Szabó, K. and Hámori, B. 2006).
In global tourism rural tourism is a refreshing phenomenon, which can help domestic and foreign tourists to learn about, better understand and sustain our country, our culture and our traditions, as well as to increase their respect to nature, to meet their desire for authentic experiences, all of which can significantly contribute to economic growth.

Today, the study of the role and opportunities of rural tourism has growing importance in academic research and professional community; however, in the policy of tourism, at national level, it hardly enjoys priority, because of its economic performance. The importance of the issue is also supported by the fact that the number of European conferences organised by the Tourism World Organization has been steadily growing.

This paper seeks to answer the questions in what forms and dimensions value-oriented

\footnotetext{
${ }^{1}$ School of Tourism, Leisure and Hospitality, BKF University of Applied Sciences, H-1148 Budapest, Nagy Lajos király útja 1-9. E-mail: nkulcsar@bkf.hu
} 
consumption appears in rural tourism, and which value elements have more and which have less relevance. The study is based on a database comprising information on the attitude of 352 Hungarian rural tourists, their consumer values, and their major dimensions.

\section{Theoretical background}

\section{Interpretations of rural tourism in Europe}

The definition, the identification of rural tourism, as well as the description of its elements have been the target of several research papers. The international literature provides a wide range of definitions for the meaning of rural tourism (Roberts, L. and HaLL, D.R. 2003). Taking the focus of the supply into account, several other terminologies are available (agro-, eco-, farm-, green-, etc. tourism) regarding tourism based upon the resources of families living in rural areas. The meaning of these definitions may differ from country to country, depending on the local "country" categories, traditions and cultural relations. In the majority of cases, however, the analysis of other content features is also required besides the definition, such as the institutional background, the structure of the countryside and the settlements, geographic features, existing sectoral policies, etc. The drawback of such a multitude of definitions is that uniform regulation is not possible or only with difficulties. The definitions of rural tourism can be rather different regarding the fact that in certain countries the emphasis is laid on the farms and the role of nature, while in other countries on the agricultural activities outside the cities (HALL, D.R. et al. 2005).

Based on the motivations of tourists different layers of rural tourism can be crystallised. International practices also point out two levels of rural tourism, which in our assumption are an internal (core) service and an external (supplementary) service (Figure 1).

The above mentioned classification points out that today, regardless of the fact whether the countries consider this form of their tourism as farm-tourism, agro-tourism, green tourism or rural tourism, etc. basically two topics are in the focus:

- One of the topics which can be found in most cases is being close to nature, and the services attached to it (sledging, riding a horse cart, trekking, etc.) and programmes, including sports (cycling, mountaineering, rafting, horse-riding, etc.) and activities encouraging relaxation or learning (walking in nature, animal watching, collecting herbs or picking mushrooms, etc.).

- The other topic is being in the countryside, including rural culture, traditions and lifestyle, in which the focus is on rural, village or farm lifestyle, agricultural activities around the house, the role of domestic animals, gastronomic specialities and last but not least the relationship between the guest and the host, which is unique.

Similarly to the approach of Perales, R. (2002) on traditional-modern rural tourism, we regard the presence of "being in the countryside" as a traditional core service, while ensuring "to be close to nature" as a complementary service. Nevertheless, the weight of the layers in the touristic services i.e. which type of service has a bigger value for the tourists (the traditional or the modern) is questionable. The directions of development and the criteria of success can be identified in possession of this information.

\section{Interpretation of rural tourism in Hungary}

The definition of rural tourism applied in Hungary does not clearly define producttype tourism. The interpretation of rural tourism is becoming more and more wide-range, the boundaries of the definition are getting "blurred" and in the Hungarian literature, besides rural, the terminology of countryside or countryside-rural is continually appearing. Its basic characteristic is its complexity and the fact that it embraces several other products. Apart from providing accommodation in a village environment (on the host's 


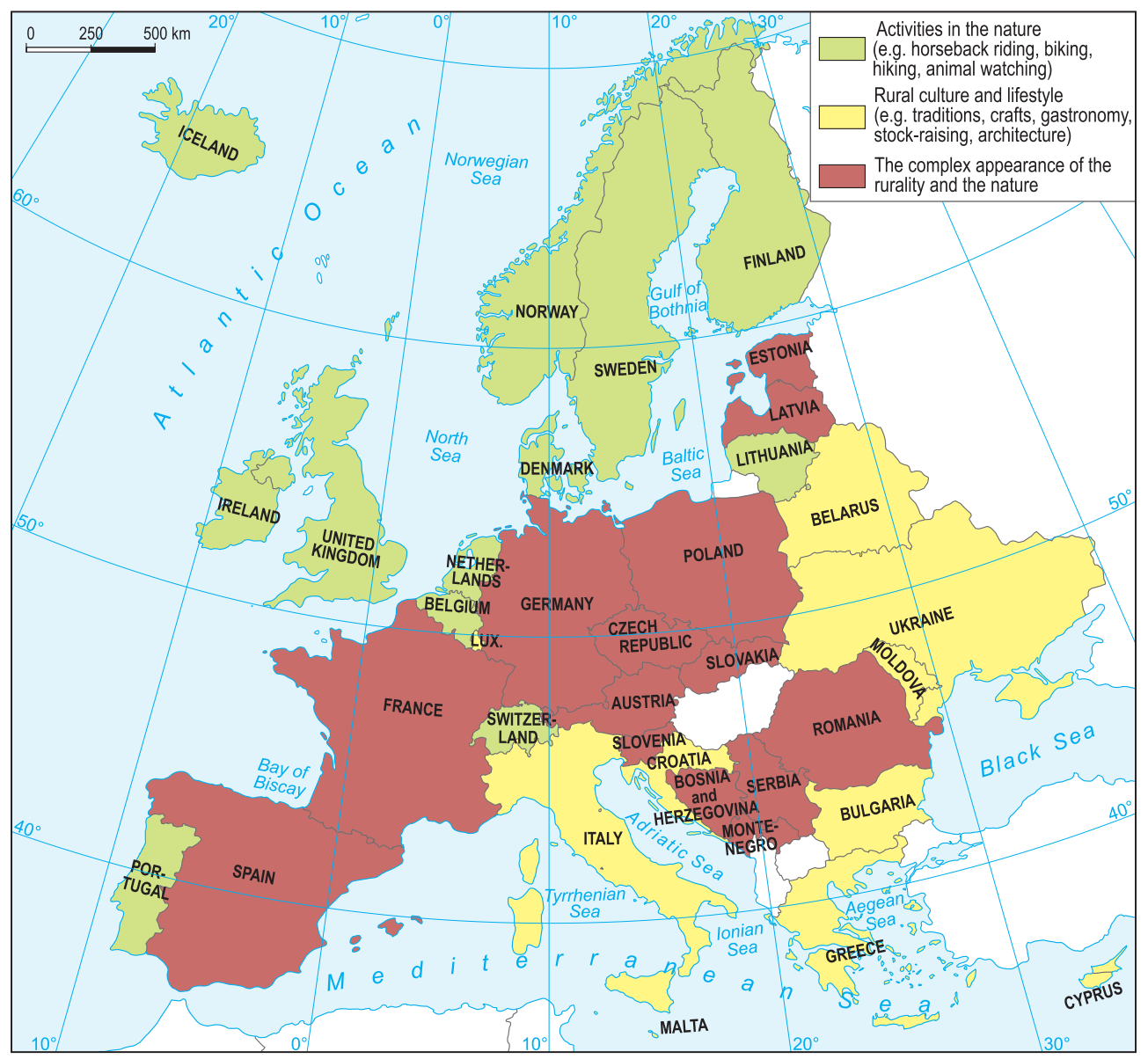

Fig. 1. The direction of tourist motivation in rural tourism of European countries. Source: Compiled by the author on the basis of EuroGites 2011, Dettori, D.G. et al. 2004, MAestro, R.M. et al. 2007, ZobenA, A. et al. 2005, Vofkori, L. 2004, Turner, C. 1993.

premises), rural tourism can include cultural offers, gastronomy, wine tourism, walks in the nature, health tourism, horse-riding and children's camps (Szabó, G. 2006).

The term "rural tourism", widely used in the European literature can be translated as countryside or village tourism as well, but regarding its direction and content elements, it can mainly be interpreted as the Hungarian - not real value - village tourism (see ANTAL, K. 1996; Kovács, D. 2002; Szabó, G. 2006; Csizmadia, L. 2011). Similarly to the international literature, the Hungarian interpretation of village tourism is also extremely colourful. In the Hungarian interpretation there is no clear dividing line between rural and countryside tourism. The National Association of Rural and Agrotourism (FATOSZ ${ }^{2}$ ) uses the term "village tourism" as a synonym for the most general form of rural tourism (SzABó, G. 2006). The term of "village tourism" known in Hungary does not clearly define a type of touristic product. It is rather its complexity and its

2 "Falusi és Agroturizmus Országos Szövetsége” in Hungarian. 
feature of embracing other products which can be regarded as a principle feature.

In accordance with the interpretation of the Strategy for the Improvement of Tourism, the narrow definition of rural tourism is "making use of the complex touristic facilities and the supply of the village, jointly offering village lifestyle, local traditions, culture and where it is available, agricultural facilities. In the broader sense of the meaning, rural tourism provides host accommodation anywhere, except for in spa and health resorts, including the village-like parts of any settlement (offering accommodation, catering and programmes) if the location and the activity meet the typical system of requirements of rural tourism" (MNE 2011:48). In its supplyside, but also demand-oriented definition, the Ministry emphasizes that experiencing new, authentic adventures, the desire to learn and get the knowledge are the most fundamental touristic motivations today.

Among the definitions found in the Hungarian literature we can find the following features of rural tourism:

- it supplements the family income,

- it is a touristic activity carried out in the countryside, and

- a provision of complex services in catering, accommodation and programmes, attached to agriculture and nature.

On the basis of all these we can assume that the interpretation of rural tourism from the Hungarian point of view is a complex form of tourism, in which village lifestyle and all the attached activities appear as the core (the basic) service of rural tourism, as the supplement of other services offered in the broader environment.

The market of rural tourism has been undergoing significant transformations. On the one hand, due to the processes affecting the countryside, and on the other hand, because of new regulations, and the effects of the new classification and specialisation systems targeting quality growth. The characteristics of

\footnotetext{
${ }^{3}$ Ministry for National Economy
}

rural tourism in Hungary can be summarised both by the supply and demand sides.

\section{a) Supply side}

- Organised rural tourism was operated in Hungary already before World War II. Holidays with full board were possible in several villages. After World War II, the system of rural tourism that had been systematically built up since the 1930s was liquidated. The organisation operating before the war had assisted rural tourism by promotion and professional propaganda of accommodations. The establishment of accommodations was achieved by the integration of villages into the system, the preparation of the hosts and making them interested in the development of their own settlements (Szabó, G. 2011).

- In the 1970s there was a shift in the objectives of tourism development in Hungary, when efforts were made to make tourism territorially more balanced in the country by the exploration of new destinations and the creation of new attractions (SzABó, G. 2011).

- The new area of village tourism starting from the late 1980s has individual characteristics and important experiences. After that rural tourism development in Hungary shows an interesting example of the diversification of household resources and exploration of hidden or unused local values for tourism development. Spontaneous development, which was the dominant characteristic of those years have been gradually replaced by a more organised and bettermanaged activity (Kovács, D. 1997).

- In the 1990s a national body (Association for Rural Tourism) was set up with a county level organisational structure established later, now operating as a professional body called National Association of Rural and Agrotourism (FATOSZ). For the qualification and quality assurance of rural tourism accommodations a criteria system was worked out. The effective marketing activities of rural tourism were also born by the end of the 1990s. Figures on the 
number of registered hosts and the capacity of accommodation in villages have been available in Hungary since 1998 (Figure 2). Until 2009 the capacity had been rising annually, however, after 2009 the number dropped to about 4 thousand hosts due to the economic crisis, and the generation change. In addition, in accordance with the 239/2009 government decree, rural accommodation is defined as accommodation at a settlement below the population threshold of 5,000 inhabitants, and below the population density of 100 inhabitants/ $\mathrm{km}^{2}$, thus as a combination of these effects the capacity almost halved after 2010. The number of hosts falling out of the circle of rural tourism for administrative/statistical reasons is considerable. This also meant that due to the new legal regulations beds in settlements with over 5,000 populations, including towns with scattered farmsteads on their outskirts, or rural parts of small towns, were no longer registered as village accommodations in 2010. Due to the changing regulation village tourism can only be registered in settlements below a population density of 100 persons $/ \mathrm{km}^{2}$. The new administrative rules clearly worsened the positions of rural tourism.
- Providing village accommodation is typical mainly in Northern Hungary, and in the Western and Southern Transdanubia regions, where 60 percent of all the capacity is concentrated, while the figures are the lowest in the Central Hungary region, with only 2 percent of the total capacity (Figure 3).

- To support high quality services a national trade marking system has been established since 2011. Joining the "sunflower" national trademark system is not obligatory, but it contributes to distinguish good quality service providers from non-qualified services, to strengthen consumer consciousness and to provide guidelines for the easier selection of services. The qualification system awards 1 to 4 sunflowers to the village accommodations, depending on the comfort level and the equipment of the accommodation. The number of qualified accommodations was increasing approximately by 200 units per year reflecting the success of system. Currently 765 rural tourism accommodations are officially qualified (FATOSZ 2014).

- In the future, the new system of accommodation classification, as well as the use of National Trademark, the improvement of rural tourism products, and the crea-

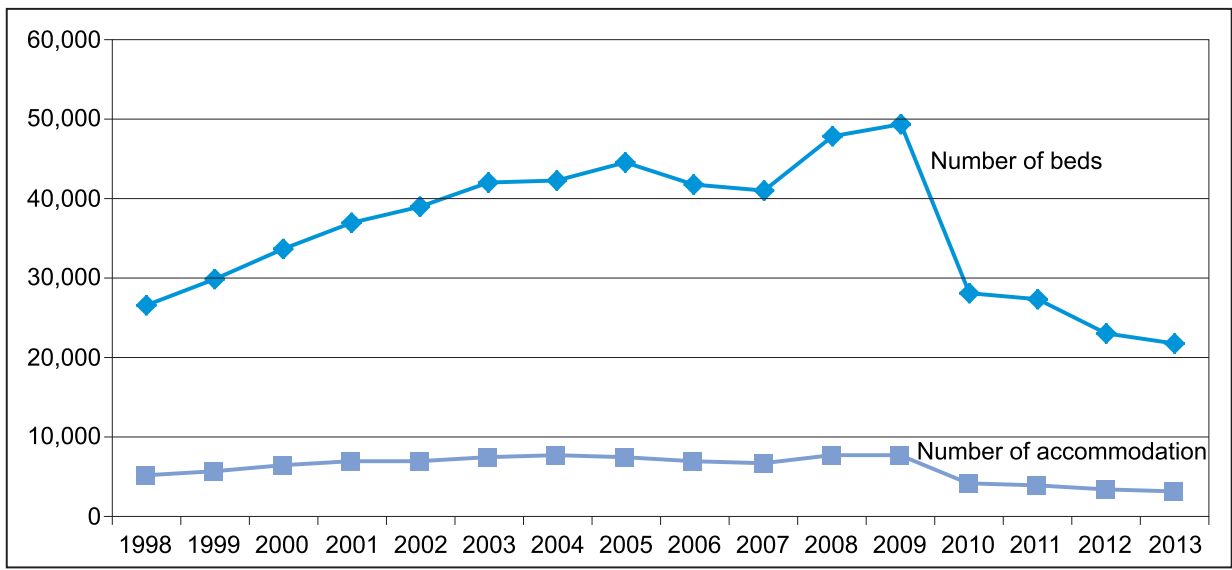

Fig. 2. The amount of rural accommodation and capacity in Hungary (1998-2013). Source: Based of figures by $\operatorname{HCSO}(2014 a)$ 


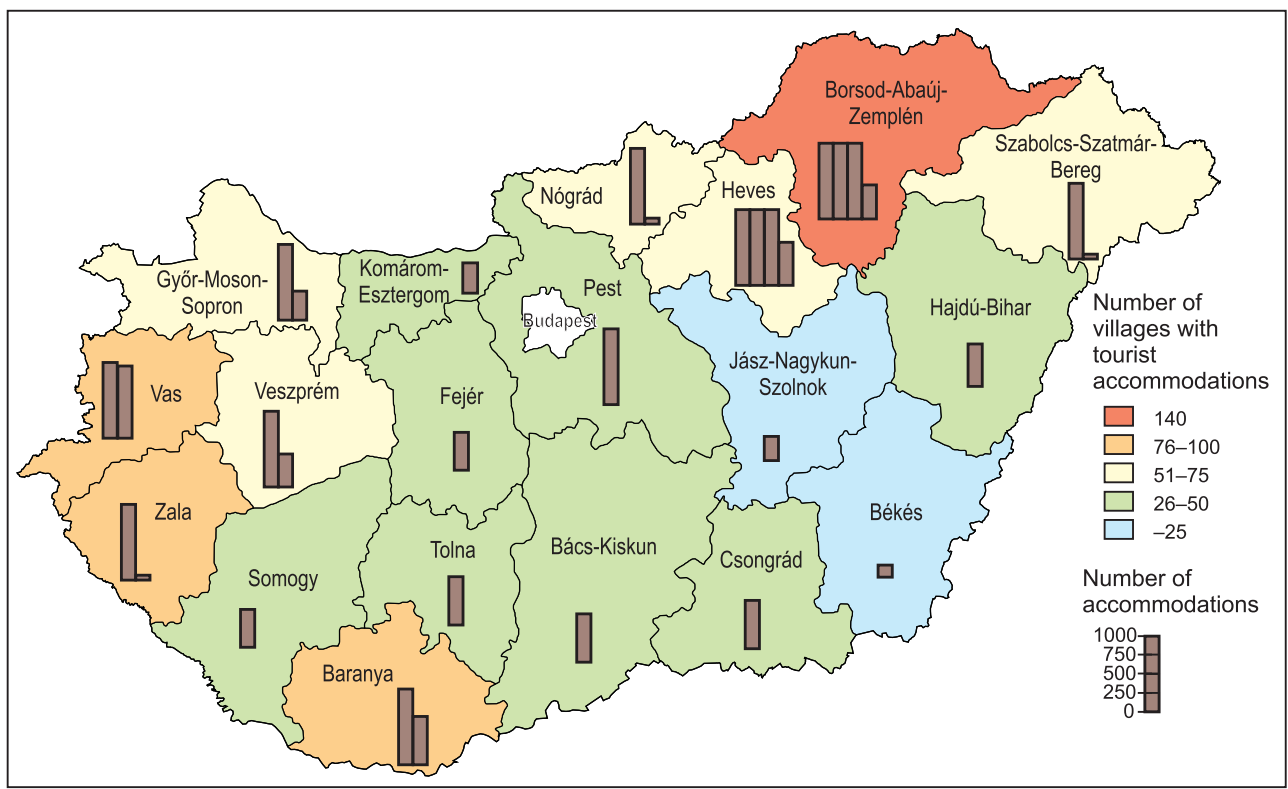

Fig. 3. Distribution of rural accommodation capacity in Hungary (on 1 January 2013). Source: Compiled by the author based on HCSO (2014b)

tion of specialised houses offering special products may all encourage the quality improvement of supply, thus can contribute to the increase of tourism.

\section{b) Demand side}

- The demand of rural tourism in Hungary was focused on inexpensive vacations for families with children, but this has changed in the past decade, however, we have to note that the price still determines the guests' decision.

- The demand side of rural tourism is closely related to the general motivation trends of tourism. Tourists show a growing interest towards unspoilt natural landscapes, clean and beautiful nature. The focus is on the desire for complete silence and tranquillity, for "perfect" recreation which may bring about the appreciation of "untouched" rural areas as tourism destinations, too. Another trend is the individualisation, the appearance of individual demands and desires of the guests. The chances of places with unique image - smaller, friendlier boarding houses - and of destinations suitable for the satisfaction of hobby needs - e.g. nature watch, bird photography are improving. Similarly, the demand for theme products, products of definite units of offers is increasing. Satisfaction of the hobby needs and the individual requests will become a major demand trend. It is also true, that the positions of hosts who are unique but are also able to meet high quality demands tend to improve. The tourists expect tidy, well-kept and comfortable accommodations and an environment in the destination that offer at least the level of their own homes. This is a great challenge for hosts in the villages. A clear-cut demand is, in addition to the comfortable accommodation, the intimate and familylike atmosphere and the civilised and tidy environment (SzABó, G. 2011). 
- The peak year of the registered demand in rural tourism in Hungary was 2008 (Figure 4). The number of guest nights in that year exceeded 744,000. In the following years demand gradually shrank, and by 2013 the number of guest nights fell by almost 50 percent, as compared to the peak year (HCSO 2014a).
- In rural areas of the European countries qualified accommodations have moved towards programming and now they have unique, special offers. Hungary also has taken the first steps in this direction. Services also have to adjust to the expectations of the customers (e.g. specialisation of farms: active, equestrian, eco, health, wine).

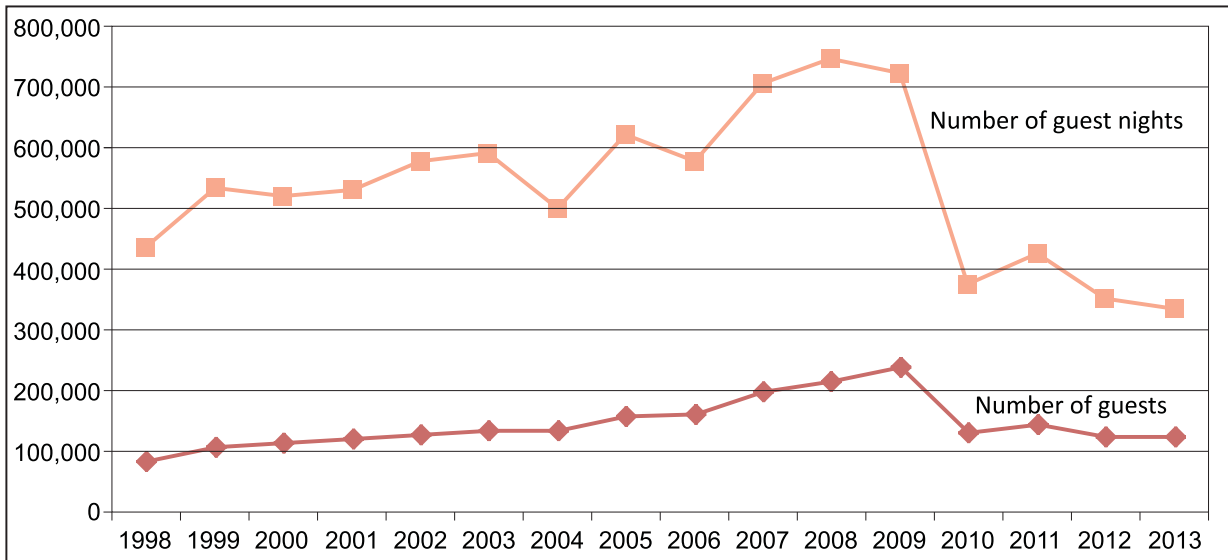

Fig. 4. The number of guests and guest nights in rural tourism in Hungary (1998-2013). Source: Based on figures by HCSO (2014a)

- The decrease had several reasons (Szabó, G. 2012): shrinking market due to the economic crisis; the earlier introduced Government Regulation, which regulated the classification of accommodations unfavourably; changes of the tax regulations in 2010, which terminated the tax exemption of rural accommodation provision (up to the income of 800,000 HUF, ca. 3,000 EUR) and also that of the linked services (up to the income of 400,000 HUF).

- The majority of guests in rural tourism (90\%) are definitely Hungarians today. While the proportions of foreign and domestic guests were almost equal around the millennium, but since then significant rearrangement has taken place. In 2008, the best year of rural tourism so far, the number of guest nights by domestic guests was approximately six times higher than the number of nights spent by foreigners (Szabó, G. 2011).
Improving the competitiveness of rural tourism enjoys high priority both in Hungary and abroad. The issue of competitiveness and the improvement of the quality of life are important parts of Hungarian strategies focusing on the development of tourism. These strategies place the emphasis on touristic development trajectories that are guided by value-orientation and market demand, the starting point of which is that the values provided by tourism, the experiences and the motivations of tourists are equally considered $^{4}$.

\footnotetext{
${ }^{4}$ We use the terminology of experience in a positive sense here. The term experience in English language means the knowledge or practical wisdom gained from what one has observed or a way that creates a memorable event. In Hungarian language separate terms are distinguished for these definitions, but we have to take into consideration that the English term is context-dependent.
} 
The role of consumer value

The concept of consumer value can be examined from different aspects: we can take the approach of product-oriented sales (Sснмітт, B.H. 2003 In: Kozma, M. 2009), KotLeR's marketing concept (see Kotler, P. 2003 In: Hou, L. and TANG, X. 2008), as well as the recently introduced $\mathrm{CRM}^{5}$, or consumer experience management (Schultz, D.E. 2003 In: Kozma, M. 2009). According to these new interpretations consumer value reflects the largely subjective (Hofmeister, T.Á. et al. 2003) or personal opinion of the consumer as to what extent the received product or service meets his expectations (PARASURAman, A. et al. 1985).

According to Chikán, A. and Demeter, K. (2004) consumer value is created if the benefit of the consumer from a given transaction exceeds the complete cost of the possession of the received product and the service package.

This subjective definition of value is rather comprehensive, which we can unfold through the definition of value dimensions (Gelei, A. 2006). Value dimensions deconstruct customer value into its elements, showing which major components or dimensions of the received product- or service package can significantly contribute to the growth of customer value (Walters, D. 2002 In: GeleI, A. 2006).

As a summary, we can say that the literature defines customer value in one-dimensional and in multi-dimensional sense of the meaning. Researchers defining customer value along one dimension, place the emphasis on the transactional value, where the consumer values the difference between the received product/service and the price paid for acquiring it. Other authors often define customer value as a multidimensional perceived value, describing it as "complex" (LAPIERre, J. 2000), "having several factors" (BABIN, B.J. et al. 1994), "dynamic" (Woodruff, R.B. 1997; Parasuraman, A. and Grewal, D. 2000) or "subjective" (Zeithaml, V.A. 1988).

\footnotetext{
${ }^{5}$ Customer Relationship Management
}

The analysis of multi-dimensionality is a relevant approach for the unfolding of consumer value dimensions present in tourism. The following dimensions can appear among the components of consumer value:

- on the one hand, dimensions may appear that derive from rational (cognitive) decision and focus on functionality (e.g. the price and quality of the service elements), - on the other hand, affective dimensions may turn up that have an effect on the consumer product-related perception (such as atmosphere, feelings, relationships, experiences).

The basis of every company's (in this case, touristic service providers) long-term success and competitiveness is the long-lasting satisfaction of their consumers, which occurs if they can create value for them. Therefore, the definition of consumer value components and dimensions is highly critical in tourism as well (YUAN, Y-H.E. and Wu, C.K. 2008). In the field of tourism there are relatively few studies on the identification and measurement of consumer value dimensions (SÁNCHEZ, J. et al. 2006), nevertheless, we can assume, based on the achieved results, that due to its being so abstract, impossible to conserve, heterogeneous and complex, the one-dimensional (trade-off) model of value would be too simple to define consumer value with. Instead of the functional (mainly price and quality based) approach, the socio-psychological approach might be appropriate (Williams, P. and Soutar, G.N. 2000).

We can say that consumers can acquire values from different types of experiences. Experience value compared to consumer value focuses on value components, which are preserved in the consumer after these experiences. Thus, there are a lot of similarities between experience value and consumer value, yet, research on experience value is rare. YUAN, Y-H.E. and Wu, C.K. (2008) used the consumer value concept for the measurement of experience value, since most researchers of the field agree that the major dimensions of consumer value are made up of emotional and functional characteristics. 


\section{Research methods}

Despite the fact that models of consumer value have already been adapted in the literature on tourism, empirical studies are not very widespread. The basis of success of rural tourism in Hungary could be the identification of tourists' motivations, attitudes, as well as factors that carry value for them, since it may reveal useful information both scientifically and practically.

In our quantitative research a double questionnaire survey was carried out. We conducted our survey in cooperation with the National Association for Rural and Agrotourism. Within the frame of this cooperation, the association helped us choose and get in contact with touristic service providers in the regions of Hungary, where the number of guests in rural tourism is outstanding and the activity of the enterprise is successful. Sampling was based on expert recommendation. Using the method of non-probability sampling, we sent questionnaires to 25 touristic businesses distributed in all counties and regions, where they had it completed by their guests with the method of convenience sample. Our aim was to study the characteristics of guests participating in rural tourism at a certain point in time, thus, we must also take caution to not use results from this sample to generalize to a wider population.

We sent out 300 questionnaires altogether. Out of the received 148 questionnaires, we could process 132 questionnaires. When selecting the subjects an important principle was representativeness and randomness, which means that the sample should approximately have the same features statistically as the mass (guests taking part in rural tourism) to be analysed. Nevertheless, since in Hungary the characteristics of the guests are not known, and we do not have exact figures about the basic mass is the conditions of representativeness cannot be controlled.

We forwarded our retrospective online questionnaire $(\mathrm{N}=220)$ to tourists who already took part in rural tourism in the last 3 years and who have valuable observation.
With the double questionnaire survey our aim was to investigate if there is a significant difference in the answers of consumers interviewed on the location and in the form of retrospective online research. The questionnaire consisted of closed, nominal ordinal, semantic differential questions and questions measured on the Likert-scale.

\section{Research results}

During the analysis we applied descriptive statistics, primarily frequency analyses, and multi-variant data analysis techniques, crosstabs-analysis, and factor analysis with the help of SPSS 18 statistical program package.

Based on the major aspects of the analysis, the results of the questionnaires conducted on the field $(\mathrm{N}=132)$ and online $(\mathrm{N}=220)$ were compared, so that we can learn basic differences. It was also important to investigate whether the composition of the samples from two different sources is different or not. Independent two-sample t-test was used to test the significance.

The compared data (gender $(p=0.074)$, sender region $(p=0.367)$, tourist motivation $(p=0.956)$, interpretation of rural tourism $(p=0.476)$ and region of holiday $(p=0.258))$ confirmed that the composition and preference of the two samples did not contain any significant differences, moreover, they rather tended to strengthen each other, so we will continue to analyse the data together, in a 352 subject sample.

The content and interpretation of domestic rural tourism - Based on consumer responses

In our research we were particularly interested to know how today's touristic trends (ETC 2006) - individual consumption, conscious travelling, the search for authenticity and value, complex touristic packages - can influence Hungarian rural tourism. What is the key motivation of tourists when they choose rural tourism, and what does rural 
tourism mean to them? The findings show that in Hungary the consumers of rural tourism choose this form in order to experience the countryside $(27.8 \%)$, but apart from that, there is a group of consumers for whom undisturbed relaxation in itself is a major motivation (26.1\%) (Figure 5).

Examining the motivations by age groups, we can see a significant, medium strong relationship between the variants (Figure 6). On the basis of the findings we can say that 35 percent of young adults and 30.5 percent of the middle age people arrive at the destination with the purpose of experiencing the countryside in a complex way. Also in the same age groups, the motivation of relaxation is 29.1 and 23.7 percent respectively.

In the group of young adults, relaxing in a peaceful environment has a stronger motivational force $(31.1 \%)$ than complexity $(24.6 \%)$. For the elderly generation the major motivation to select rural tourism besides relaxation $(17.2 \%)$ and complexity $(17.2 \%)$ is the vicinity of nature $(13.8 \%)$, experiencing nostalgia (13.8\%) and real hospitality (13.8\%).

At the level of 95 percent validity we can see a significant correlation between the motivation of consumers and the receiving

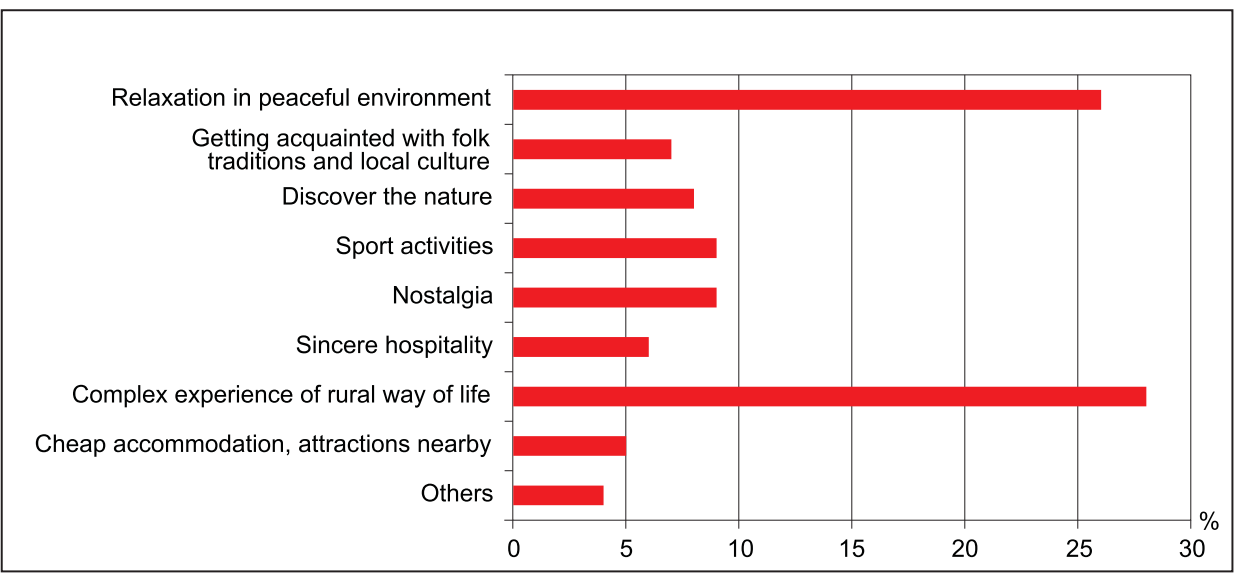

Fig. 5. Distribution of the sample based on motivation, Source: Kulcsár, N. 2013

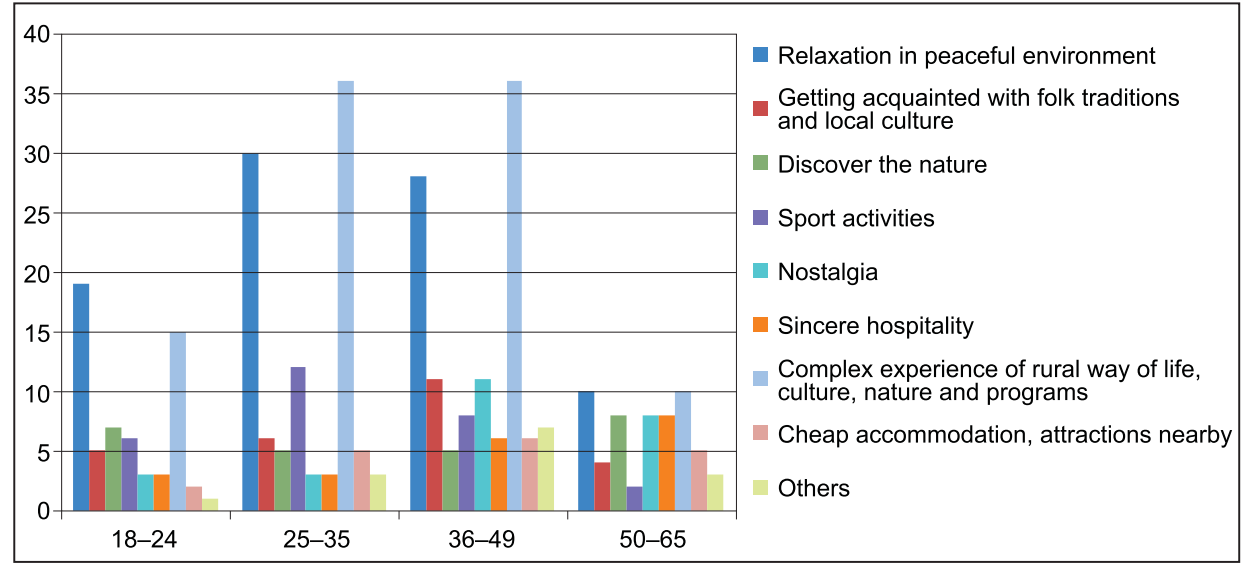

Fig. 6. Distribution of motivations according to age $\left(\chi^{2}=38.367 ; \mathrm{df}=24 ; \mathrm{p}=0.032\right)$. Source: Kulcsár, N. 2013 
destinations too. Tourists looking for the complex experience of the countryside as well as peaceful relaxation, willingly choose Northern Hungary, Western Transdanubia and Central Transdanubia for the location of their holidays.

Travellers seeking to experience genuine hospitality mostly choose the Northern Hungary region $(28.6 \%)$. If the guests want to experience a nostalgic atmosphere, they prefer to choose the region of the Southern Great Plain region $(32.1 \%)$, as well as Northern Hungary. For sports lovers the primary destination is hilly Northern Hungary (21.4\%) and Central Transdanubia (17.9\%). Regarding most motivational factors (culture, nature, calmness, sport, hospitality), Northern Hungary is the most popular region, yet those travelling to seek nostalgic feelings, usually choose the Southern Great Plain region as their destination.

The order of motivations can change according to age groups, destinations, residence and people travelling together. On the whole, from the findings of the research we can draw the conclusion that in the first place tourists choose rural tourism because of the values of nature and local programmes, while visiting the sights of the surrounding area comes in the second place and in the third place learning about the country lifestyle and activities around the house could be recorded (Table 1). culture, nature and authentic programmes, although the most important for them is discovering the values of nature and recreation in fresh air in a beautiful environment. Thus, a new model of Hungarian rural tourism could be set up based on international practices (see Figure 1 above) and our pilot study where nature-orientation is in the internal, essential circle, while country lifestyle, culture and heritage belong to the circle of supplementary services.

\section{Consumer value dimensions in rural tourism}

In order to identify the latent structures behind the consumer's responses namely the consumer value dimensions of rural tourism, firstly 33 value indicators were identified, and their importance was examined. The consumers indicated on a 1-4 point evaluation scale how important the different indicators are. After all a factor analysis on these value indicators was carried out. The main aim was to measure the dimensions and relevance of these factors, setting up the order of their importance.

The factor analysis was conducted with Varimax rotation. The method serves data compression and the identification of data structure, where the number of initial indicators is contracted into factor variants, which are directly non-observable. The adaptability

Table 1. Order of preference of programs

\begin{tabular}{c|l|c|c|c}
\hline Ranking & \multicolumn{1}{|c|}{ Programme preference } & Online & On site & Together \\
\hline 1. & Hiking and discover the nature & 544 & 387 & 931 \\
2. & Visiting the main attractions of the surrounding area & 638 & 383 & 1,021 \\
3. & Getting acquainted with farm activities around the house & 802 & 460 & 1,262 \\
4. & Participating in traditional programmes** & 806 & 459 & 1,265 \\
5. & Visiting festivals & 814 & 547 & 1,361 \\
6. & Silent passive activities*** & 916 & 536 & 1,452 \\
\hline
\end{tabular}

${ }^{*}$ E.g. vintage, bread baking, canning, ${ }^{* *}$ E.g. crafts, folk-dancing, ${ }^{* * *}$ E.g. reading, board games.

Source: Kulcsár, N. 2013

We can conclude that in accordance with the European trends in tourism the majority of consumers in rural tourism travel to experience the complexity of country lifestyle, of indicators for factor analysis was tested by the Kaiser-Meyer-Olkin (KMO)-criterion, and the variance quotient methods. After the factor analysis of indicators linked to the physi- 
cal environment and human interactions, 10 factors were separated ${ }^{6}$ :

F1. Host attitude: it is important for the guests that the host is helpful and friendly, and has information about the touristic attractions and events of the area.

F2. Attractive accommodation: it is important for the guests that the accommodation is nicely decorated both inside and outside.

F3. Clean, well-equipped accommodation: it is important for the guests to have clean and well-maintained accommodation, equipped with comfortable furniture.

F4. Interaction and activity at the accommodation: it is important for the guests to have a stay which is rich in impulses, i.e. to have personal contacts and be part of the programmes during their stay.

F5. Authentic accommodation: it is important for the guests that the rural accommodation represents authenticity and has the typical features of traditional folk architecture both inside and outside.

F6. Peaceful relaxation: it is important for the guests that during their holiday they have a harmonious relationship with the local people and with other guests, not disturbing each other's activity.

F7. Presence of animals: it is important for the guests to see domestic and farm animals on the host's premises.

F8. Nicely arranged, clean settlement: it is important for the guests that the accommodation is located in a clean, nicely arranged and peaceful settlement surrounded by nice environment.

F9. Online availability: it is important for the guests also to receive information of the host's services and get in touch with him online.

F10. Cheap accommodation close to a major attraction: it is important for the guests to have a low-priced accommodation, not far from the major tourist attractions of the area.

Finally, after the factor analysis we averaged all factors based on the value of impor-

\footnotetext{
${ }^{6}$ In our research the method of factor analysis was Principal Component Analysis. The number of factors was determined based on the elbow criterion and the explained variance.
}

tance of their indicators ${ }^{7}$. As a result, we got the importance of the given indicator group (factors), from which we drew the conclusion that for guests the most important group of indicators during their rural holiday is the orderliness and cleanliness of the settlement (destination), followed by the neat and attractive arrangement of the accommodation, while the third group of indicators in rank is the personality, preparedness and helpfulness of the host (Table 2).

Interpreting the order of the factors we can conclude that for rural tourists indicators linked to the conditions of the physical environment are of greater importance than those linked to the human factors. Apart from this we can see that the strive for "modernisation" is valid for the analysed circle of consumers.

Based on the results of the factor analysis and the ranking regarding value indicators, we conclude that for tourists in rural tourism functional (quality, price) value dimensions are of primary importance, they have a greater value than affective experience dimensions (recreation, human relations and activity, environment) (Table 3).

The answer to our research question is that for consumers the most important value dimension in rural tourism seems to be quality, i.e. the functional arrangement of the accommodation and the host. These are followed by factors like peaceful relaxation, and appropriate price in the third place, and experience through personal interactions and programs in the fourth position. The fifth value dimension is the experience in an authentic country environment.

\section{Conclusions}

The primary aim of our research was to conduct a survey in rural tourism, which can contribute to the better understanding of the demand side and crystallise the factors with value to tourists, helping the better elabora-

\footnotetext{
${ }^{7}$ Importance of indicators come from consumers' responses given to the survey questions with an evaluation scale ( 1 = not important; 4 = very important).
} 
Table 2. The order of importance and dimensions of rural tourism's consumer value factors

\begin{tabular}{|c|c|c|c|c|}
\hline Ranking & Value factors & $\begin{array}{l}\text { Number of } \\
\text { indicators }\end{array}$ & Mean & Dimensions \\
\hline $\begin{array}{l}1 . \\
2 . \\
3 .\end{array}$ & $\begin{array}{l}\text { Nicely arranged, clean settlement (F8) } \\
\text { Attractive accommodation (F2) } \\
\text { Host attitude (F1) }\end{array}$ & $\begin{array}{l}2 \\
3 \\
7\end{array}$ & $\begin{array}{l}3.63 \\
3.51 \\
3.49\end{array}$ & Functional (Quality) \\
\hline 4. & Peaceful relaxation (F6) & 3 & 3.42 & $\begin{array}{l}\text { Affective (Experience - rec- } \\
\text { reation) }\end{array}$ \\
\hline $\begin{array}{l}5 . \\
6 . \\
7 .\end{array}$ & $\begin{array}{l}\text { Clean, well-equipped accommoda- } \\
\text { tion (F3) } \\
\text { Online availibility (F9) } \\
\text { Cheap accommodation closer to } \\
\text { major attractions (F10) }\end{array}$ & $\begin{array}{l}5 \\
2 \\
2\end{array}$ & $\begin{array}{l}3.39 \\
3.29 \\
3.17\end{array}$ & Functional (Quality) \\
\hline 8. & $\begin{array}{l}\text { Interaction and activity at the accom- } \\
\text { modation (F5) }\end{array}$ & 4 & 2.98 & $\begin{array}{l}\text { Affective (Experience - hu- } \\
\text { man interactions, activities) }\end{array}$ \\
\hline $\begin{array}{r}9 . \\
10 .\end{array}$ & $\begin{array}{l}\text { Authentic accommodation (F5) } \\
\text { Presence of animals (F7) }\end{array}$ & $\begin{array}{l}2 \\
1\end{array}$ & $\begin{array}{l}2.89 \\
2.64\end{array}$ & $\begin{array}{l}\text { Affective (Experience - mi- } \\
\text { lieu) }\end{array}$ \\
\hline
\end{tabular}

Source: Kulcsár, N. 2013

Table 3. Order of importance of consumer value dimensions

\begin{tabular}{c|l|c|c}
\hline Ranking & \multicolumn{1}{|c}{ Consumer value dimensions } & Number of factors & Mean \\
\hline 1. & Functional (Quality) & 5 & 3.46 \\
2. & Affective (Experience - recreation) & 1 & 3.42 \\
3. & Functional (Prize) & 1 & 3.17 \\
4. & Affective (Experience - human interactions, activities) & 1 & 2.98 \\
5. & Affective (Experience - milieu) & 2 & 2.77 \\
\hline
\end{tabular}

Source: Kulcsár, N. 2013

tion of development strategies and matching the supply to consumers 'expectations. We believe, the scientific significance of this study lies in the fact that the interpretation and measurement of consumer value seen in rural tourism is going to fill a gap in the literature of tourism management. Based on the research findings, it will be possible to plan the supply or product development and the marketing strategy of the product in practice.

As a conclusion we can also note that the characteristics of Hungarian rural tourists have slightly changed compared to what was seen years ago (see Kiss, K. 2001). According to this earlier qualitative research the participation of city professionals, mainly pensioners or families with small children was significant, but young people without children were also a major segment of demand. In our current study, the group of elderly professionals represents a smaller proportion, with mainly the middle-aged professionals making up the demand of rural tourism, who travel to seek the countryside atmosphere. The second most important segment is the group of young people wanting to escape from the city, who usually travel with their children. They look for the safe and beautiful countryside, where they can show the flora and the fauna, the features of life outside the city, to their children. In our sample young people who are attracted to the countryside by relaxation and entertainment facilities were under-represented.

We cannot say that rural tourism is mostly chosen by people in favour of traditional values, who do not want to keep up with the accelerated modernisation or are not affected by the idea of globalisation. Guests with pro- 
gressive ideas but with less commitment to traditional values are also represented in a similar proportion in domestic rural tourism. On the other hand, we can say that most guests consider themselves materialistic, so for them it is important to buy the service at the lowest possible price, although this does not mean the highest priority. These conclusions are affected, on the one hand, by the type of product, since compared to most touristic products rural tourism offers its services at more favourable prices, but on the other hand, we must not forget that recent unfavourable changes in the world economy also had an impact on tourism.

For our sample it was not of major importance to have authentic accommodation, and that it represents folk style in its architecture or equipment. They prefer to stay in a house which is well-equipped according to contemporary requirements or expectations. Having animals around the house is important for the segment where parents want to show them to their children. In our opinion own local values are losing their significance, which is the effect of the spread of global values, and the fact that today's tourists seek a high level of comfort.

Our findings also showed that although getting the experience is important for rural tourists, in Hungary it does not outrun functional value dimensions. For the interviewed consumers, the most important value dimension was quality, that is, the functional arrangement of the accommodation and the personality of the host. It was followed by peaceful relaxation, then appropriate price in the third place, while in the fourth place we can find the need for experience through personal interactions and programs, and the fifth value dimension is experiencing the authentic environment. In author's opinion, the results in this field were also influenced by the fact that so far only few really creative products have appeared in Hungary and the supply of experience industry is currently under development, so tourists could only see a very low number of thematic experience packages.

\section{REFERENCES}

Antal, K. 1996. A falusi turizmus - mint sajátos turisztikai termék - helye és szerepe a magyar idegenforgalomban (The place and role of rural tourism - as a special tourism product - in Hungarian tourism). In A falusi turizmus, mint a vidéki térségek megúiútásának egyik esélye. Ed.: CsAró, T., Szombathely, FTOSZ-MTA RKK, 28-33.

BAbIN, B.J., DARDEN, W.R. and GRIFFIN, M. 1994. Work and/or Fun: Measuring Hedonic and Utilitarian Shopping. Journal of Consumer Research 20. (4): 644-656.

Chikán, A. and Demeter, K. 2004. Értékteremtő folyamatok menedzsmentje (Management of value creation process). Budapest, Aula Kiadó, 600 p.

Csizmadia, L. 2011. A falusi turizmus múltja, jelene és jövője (Past, present and future of rural tourism). Zsámbok, Conference presentation on 13. 08. 2011.

Dettori, D.G., PABA, A. and Pulina, M. 2004. European Rural Tourism: Agrotouristic Firms in Sardinia and Their Life Cycle. Working Paper, CUEC. http:// crenos.unica.it/crenos/files/wp/04-03.pdf (04. 02. 2007.)

ETC 2006. Tourism Trends for Europe. European Travel Commission. Brussels, 10 p. http://www.etccorporate.org/resources/uploads/ETC_Tourism_Trends_ for_Europe_09-2006_ENG.pdf (20.03. 2007.)

EUROGITES 2011. Countryside Tourism in Europe. Presentation. http://www.eurogites.org/news. php?lang=EN (10. 09. 2011.)

FATOSZ 2014. Professional newsletter, December 2014.

GeleI, A. 2006. Beszállitó-típusok és azok alapvető kompetenciái a hazai autóipari ellátási láncban (Supplier-types and their core competencies in the domestic automotive supply chain). Ph.D dissertation. Budapest, Corvinus University of Budapest, 138 p.

Hall, D.R., Roberts, L. and Mitchell, M. 2005. New directions in rural tourism. Ashgate, Aldershot, Hants.

HCSO 2014a. Jelentés a turizmus 2013. évi teljesitményéről (Report on the performance of tourism in 2013). Budapest, Hungarian Central Statistical Office, 23 p. http://www.ksh.hu/docs/hun/xftp/idoszaki/jeltur/jeltur13.pdf (30. 01. 2015).

HCSO 2014b. Dissemination database. Budapest, Hungarian Central Statistical Office, http://statinfo. ksh.hu/Statinfo/haViewer.jsp (23.05.2015).

Hofmeister, T.Á., Simon, J. and Sajtos, L. 2003. A fogyasztói elégedettség (Customer's satisfaction). Budapest, Alinea Kiadó, 37 p.

Hou, L. and TANG, X. 2008. Gap Model for Dual Customer Values. Tsinghua Science and Technology 13. (3): 395-399. KIss, K. 2001. Falusi turizmus - eltérő értelmezések, eltérő piaci lehetőségek? (Rural tourism - different interpretations, different market opportunities?) Turizmus Bulletin 5. (1): 19-32. 
Kotler, P. 2003. Marketing Management. $11^{\text {th }}$ Edition, New Jersey, Pearson Prentice Hall.

Kovács, D. 1997. Phases of rural/village tourism development. Actors of the European Countryside. Seminary, 1-5 October, 1997. Erdötarcsa, 17 p.

Kovács, D. 2002. Falusi turizmus. Azátalakuló mezőgazdaság és a vidék gazdaságának egyik diverzifikációs lehetôsége Magyarországon (Rural tourism. A diversification possibility of transforming agriculture and rural economy in Hungary). Ph.D dissertation, Gödöllo”, Szent István University, $170 \mathrm{p}$.

Kozma, M. 2009. Értékteremtés Public-Private Partnership keretében - különös tekintettel a vállalkozó szempontjaira (Value creation in a Public-Private Partnership framework - in particular aspects of the entrepreneur). Ph.D. dissertation. Budapest, Corvinus University of Budapest, $183 \mathrm{p}$.

Kulcsár, N. 2013. Analyzing the Consumer Value Dimensions of Rural Tourism. Ph.D dissertation, Budapest, Corvinus University of Budapest, 155 p.

Lapierre, J. 2000. Customer-Perceived Value in Industrial Contexts. The Journal of Business $\mathcal{E}$ Industrial Marketing 15. (2-3): 122-140.

Maestro, R.M., Gallego, P.A. and Requejo, L.S. 2007. The moderating role of familiarity in rural tourism in Spain. Tourism Management 28. (4): 951-964.

MNE 2011. Turizmusfejlesztési stratégia (Strategy for tourism development). Budapest, Ministry for National Economy, 51 p.

Parasuraman, A. and Grewal, D. 2000. The Impact of Technology on the Quality- Value-Loyalty Chain: A Research Agenda. Journal of the Academy of Marketing Science 28. (1): 168-174.

Parasuraman, A., Zeithaml, V.A. and Berry, L.L. 1985. SERVQUAL: A Conceptual Model of Service Quality and Its Implications for Future Research. Journal of Marketing 49. 41-50.

Perales, R. 2002. Rural tourism in Spain. Annals of Tourism Research 29. (4): 1101-1110.

Roberts, L. and Hall, D.R. 2003. Rural tourism and recreation: Principles to Practice. Cambridge (USA), CABI Publishing.

SÁnchez, J., Callarisa, L., Rodríguez, R.M. and Moliner, M.A. 2006. Perceived value of the purchase of a tourism product. Tourism Management 27. 394-409.

Sснмітт, B.H. 2003. Customer Experience Management - A revolutionary approach to connecting with your customers. New Jersey, John Wiley \& Sons.

Schultz, D.E. 2003. Evolving Marketing and Marketing Communication into the $21^{\text {st }}$ Century. In Kellogg on Integrated Marketing. Eds.: IAcobUCCI, D. and Calder, B. New Jersey, John Wiley \& Sons.
Szabó, G. 2006. A vidéki jövedelemszerzési lehetôségek bövitése az idegenforgalmi tevékenységek fejlesztése révén (The expansion of rural income earning opportunities through the development of tourism activities). Budapest, National Association of Rural and Agrotourism, $46 \mathrm{p}$.

Szabó, G. 2011. Products and product specialisations in rural tourism. In Design and development of touristic products. Ed.: Michalkó, G. Pécs, University of Pécs, 19-35.

SzAвó, G. 2012. A hazai falusi turizmus helyzete és jövőképe (The situation and vision of domestic rural tourism). In A turizmus területi dimenziói. Ed.: Hanusz, Á. Nyíregyháza, Nyíregyházi Főiskola TIK, Turizmus és Földrajztudományi Intézete, 177-190.

Szabó, K. and Hámori, B. 2006. Információgazdaság. Digitális kapitalizmus vagy új gazdasági rendszer? (Information Economy. Digital capitalism or new economic system?). Budapest. Akadémiai Kiadó, $616 \mathrm{p}$.

Turner, C. 1993. Rural Tourism in Greece. Recreation, Tourism and Regional Development Workshop, Wageningen.

VofkORI, L. 2004. Falusi turizmus Erdélyben (Rural tourism in Transylvania). Budapest, MTA Társadalomkutató Központ, 139 p.

Walters, D. 2002. Operations strategy. New York, Palgrave - MacMillan.

Williams, P. and Soutar, G.N. 2000. Dimensions of Customer Value and the Tourism Experience: An Exploratory Study. ANZMAC 2000, Visionary Marketing for the $21^{\text {th }}$ century: Facing the Challenge, Queensland, Australia, 1415-1421.

Woodruff, R.B. 1997. Customer Value: The Next Source for Competitive Advantage. Journal of the Academy of Marketing Science 25. (2): 139-153.

YuAN, Y-H.E. and Wu, C.K. 2008. Relationships Among Experiential Marketing, Experiential Value, and Customer Satisfaction. Journal of Hospitality and Tourism Research 32. (3): 387-410.

Zeithaml, V.A. 1988. Consumer perceptions of price, quality, and value: a means-end model and synthesis of evidence. Journal of Marketing 52. (3): 2-22.

Zobena, A., Sumane, S. and Kalnina, A. 2005. Rural Tourism in Latvia. Rauna Tourism Association. Case Study Analysis. http://www.nuigalway.ie/research/ idari/downloads/Rural\%20Tourism\%20in\%20Latv ia.pdf (04. 02. 2007.) 


\title{
Ukraine in Maps
}

\author{
Edited by: Kocsis, K., Rudenko, L. and Schweitzer, F.
}

\author{
Institute of Geography National Academy of Sciences of Ukraine \\ Geographical Research Institute Hungarian Academy of Sciences. \\ Kyiv-Budapest, 2008, 148 p.
}

Since the disintegration of the USSR, the Western world has shown an ever-growing interest in Ukraine, its people and its economy. As the second-largest country in Europe, Ukraine has a strategic geographical position at the crossroads between Europe and Asia. It is a key country for the transit of energy resources from Russia and Central Asia to the European Union, which is one reason why Ukraine has become a priority partner in the neighbourhood policy of the EU. Ukraine has pursued a path towards the democratic consolidation of statehood, which encompasses vigorous economic changes, the development of institutions and integration into European and global political and economic structures. In a complex and controversial world, Ukraine is building collaboration with other countries upon the principles of mutual understanding and trust, and is establishing initiatives aimed at the creation of a system that bestows international security.

This recognition has prompted the Institute of Geography of the National Academy of Sciences of Ukraine (Kyiv) and the Geographical Research Institute of the Hungarian Academy of Sciences (Budapest) to initiate cooperation, and the volume entitled "Ukraine in Maps" is the outcome of their joint effort. The intention of this publication is to make available the results of research conducted by Ukrainian and Hungarian geographers, to the English-speaking

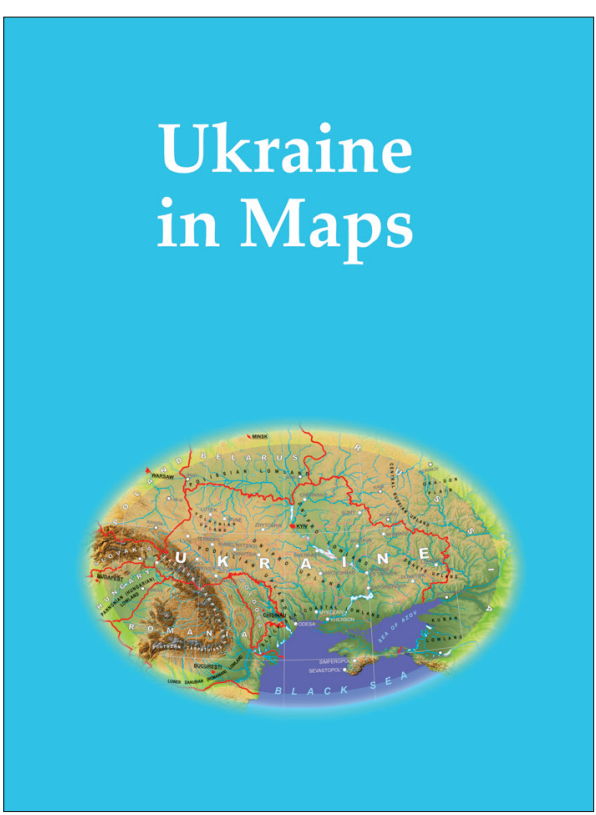
public. This atlas follows in the footsteps of previous publications from the Geographical Research Institute of the Hungarian Academy of Sciences. Similar to the work entitled South Eastern Europe in Maps $(2005,2007)$, it includes 64 maps, dozens of figures and tables accompanied by an explanatory text, written in a popular, scientific manner. The book is an attempt to outline the geographical setting and geopolitical context of Ukraine, as well as its history, natural environment, population, settlements and economy. The authors greatly hope that this joint venture will bring Ukraine closer to the reader and make this neighbouring country to the European Union more familiar, and consequently, more appealing.

Price: EUR 35.00

Order: Geographical Institute RCAES HAS Library

H-1112 Budapest, Budaörsi út 45.

E-mail: magyar.arpad@csfk.mta.hu 